\title{
QUALITY OF REFRIGERATED RAW MILK FROM BUFFALO COWS (Bubalus bubalis bubalis) IN DIFFERENT FARMS AND SEASONS IN BRAZIL
}

\section{QUALIDADE DO LEITE CRU REFRIGERADO DE BÚFALA (Bubalus bubalis bubalis) EM DIFERENTES FAZENDAS E ESTAÇÕES DO ANO NO BRASIL}

\author{
Ricardo Lacava Bailone ${ }^{1 *}$ \\ Ricardo Carneiro Borra ${ }^{2}$ \\ Roberto de Oliveira Roça ${ }^{1}$ \\ Luis de Aguiar ${ }^{3}$ \\ Moira Harris ${ }^{3}$ \\ ${ }^{1}$ Faculdade de Medicina Veterinária e Zootecnia - UNESP, Botucatu, SP, Brazil. \\ 2Universidade Federal de São Carlos, São Carlos, SP, Brazil \\ ${ }^{3}$ Harper Adams University, Newport, Shropshire, United Kingdom \\ *Author for correspondence - ricardo.bailone@agricultura.gov.br
}

\begin{abstract}
The present research aimed to examine the chemical and microbiological characteristics of refrigerated raw milk collected from buffalo-only dairy herds from different farms and seasons. Samples were collected from twelve farms producing buffalo milk, located in the Mideast region of São Paulo state, in Brazil, once a month throughout the dairy calendar year from 2011 to 2014. The analysis of fat, protein, lactose, dry extract, and total solids contents were carried out using Infrared Absorption. Residues for antimicrobial analysis were carried out using Delvo Test Kit technique, and both somatic cell count and standard plate count analysis were carried out using Flow Cytometry. The analysis of the chemical components as well as for the microbiological analysis of SPC proved to be statistically significant throughout the period. No antibiotic residues were found in the totality of the sample, hence indicating that the farmers complied with the current sanitary legislation in that country, as well as SCC; however, higher values were found for the SPC. Significant results for all parameters analyzed were found among the farms, indicating that price incentives paid for the quality of raw milk could be an alternative to dairy processing companies, favoring yield and quality of the final product.
\end{abstract}

Keywords: Brazil; chemical parameters; dairy; microbiological parameters; monitoring.

\section{Resumo}

O presente estudo objetivou examinar as características químicas e microbiológicas do leite cru refrigerado coletado em diferentes fazendas e estações. Amostras foram coletadas em doze fazendas 
produtoras de leite de búfala localizadas na região centro-leste do estado de São Paulo, Brasil, uma vez ao mês entre os anos de 2011 a 2014. Análises de gordura, proteína, lactose, extrato seco e sólidos totais foram realizadas utilizando-se técnica de Infra-vermelho. Análises de resíduos de antimicrobianos foram realizadas através do teste rápido Kit Delvo Test. Análises de contagem de células somáticas e contagem padrão em placas foram conduzidas através de Citometria de Fluxo. Resultados das análises dos componentes químicos, assim como da análise microbiológica de CPP, demonstraram diferenças estatísticas significativas através das estações para estes parâmetros. Em todas as amostras analisadas nenhum resíduo de antimicrobiano foi detectado, indicando que os produtores estão respeitando a legislação sanitária brasileira vigente, bem como para SCC; no entanto, valores acima do permitido foram encontrados para CPP. Diferenças significativas para todos os parâmetros analisados foram encontradas entre as fazendas investigadas, indicando que o incentivo de preço pago pela qualidade do leite cru poderia ser uma alternativa às empresas de processamento de lácteos, favorecendo o rendimento e a qualidade do produto final.

Palavras-chave: Brasil; laticínio; monitoramento; parâmetros químicos; parâmetros microbiológicos.

Received on June $16^{\text {th }}, 2016$.

Accepted onDecember $5^{\text {th }}, 2016$.

\section{Introduction}

Buffalo milk is typically of high nutritional content characterized by high levels of solid constituents. It can be consumed either fresh or used as raw material for further aggregating value by the dairy industry. Therefore, the great advantage of buffalo milk in relation to cow milk (Bos taurus sp) is precisely its amount of fat, protein, lactose, dry extract, and total solids ${ }^{(1)}$. The fat and protein elements contained in buffalo milk are partly responsible for the greater industrial efficiency in the manufacture of its buffalo-based dairy by-products, as well as for its quality ${ }^{(2)}$. Buffalo milk is nearly twice as rich in fat as compared to cow milk ${ }^{(3)}$. Varrichio et al. ${ }^{(4)}$ reported the fact that buffalo fat content had an average value of $8.3 \%$, but values of up to $15 \%$ could also be found under normal conditions. In Brazil, Macedo et al. ${ }^{(5)}$ and Tonhati et al. ${ }^{(2)}$, studying the chemical composition and production of milk from Mediterranean buffalo cows, found mean fat content of $6.59 \%$ and $6.87 \%$ respectively. However, Jorge et al. ${ }^{(6)}$ found a fat overall average of $5.10 \%$ deriving from a wide fat content variation between the herds studied.

In most developed countries, raw milk quality is defined by the Somatic Cell Count (SCC) and the total bacterial count or Standard Plate Count (SPC) present in milk tanks. Determining bulk milk SCC is an internationally recognized method to establish milk quality as well as the udder health status of the cows in the herd ${ }^{(7)}$.

According to Hashmi \& Saleem ${ }^{(8)}$, owing to the rich nutrient content buffalo products have, microorganisms can rapidly propagate specially in the liquid milk medium with detrimental effect to its commercial value. As a result, the analysis of the Standard Plate Count (SPC) is a good indicator of the state of hygiene at the dairy farm level during the phases of milking, storage, and transportation $^{(9)}$. The SPC analysis determines the concentration of microorganisms present in the milk and is a good tool for dairy hygiene quality inspectors to infer the likely adverse effect that a 
specific batch might have on a processing plant and the overall safety of the milk ${ }^{(10)}$. Higher milk hygiene at farm level provides the industry with better product to process resulting in products with longer shelf-life.

The presence of antimicrobial drugs used in the treatment of cattle infection can be traced in the milk analysis. Only in the beginning of new millennium, farmers in Brazil have become more aware of the public health implications regarding the possible harmful effects that veterinary drug residues present in foods can cause to humans. In order to safeguard human health, the World Health Organization (WHO) and Food and Agriculture Organization (FAO) have set standards for Acceptable Daily Intake and Maximum Residues Limits (MRLs) for each antibiotic present in the milk $^{(11,12)}$. These limits apply to both the parent drug or chemicals and their resulting metabolites following the administration of a drug compound to animals. These drugs may have a cumulative effect and either be deposited or stored within the animal cells, tissues, and organs ${ }^{(13)}$.

Since microbial infections in the udder change milk composition and render milk less suitable for human consumption and processing ${ }^{(14)}$, the presence of antibiotic trace products used to combat infections serves as another valuable quality parameter to be tested. Traces of antimicrobial agents found in the milk indicate that the herd has been treated against mastitis and the milk from these cows is unsuitable for human consumption. The presence of trace antimicrobial agents also indicates that farmers have not adhered to the recommended withdrawal period until its effect is elapsed as set by veterinary pharmaceutical companies.

The objective of this study was threefold: firstly, to establish the chemical (fat, protein, lactose, dry extract, and total solids); secondly, to test the somatic cell count and standard plate count, and, thirdly, to evaluate the presence of antibiotic residues in refrigerated raw milk from Murrah buffalo cows (Bubalus bubalis bubalis).

\section{Material and Methods}

For the purpose of this study, refrigerated raw milk was collected in twelve buffalo's farms (Murrah buffaloes) located in the municipality of São Carlos (Latitude $22^{\circ} 01^{\prime} 03^{\prime \prime}$ South, Longitude $47^{\circ} 53^{\prime}$ 27" West and Altitude $854 \mathrm{~m}$ ) in the Midwest region of the state of São Paulo in Brazil, typically of tropical climate with dry winters and rainy summers, being February the hottest month (average of $22.7^{\circ} \mathrm{C}$ and maximum of $37^{\circ} \mathrm{C}$ ) and July the coldest month (average of $17.3^{\circ} \mathrm{C}$ and maximum of $29{ }^{\circ} \mathrm{C}$ ). The number of animals per farm ranged from 37 to 81 and they were fed on a ratio of improved grassland (Brachiaria decumbens), sugarcane stems, and barley to supplement their diet.

The samples were taken at the arrival of the bulk milk tanker at the dairy processing plant. The procedure consisted of homogenizing the raw milk using a tank agitator for five minutes. Following this, the samples were put into sterilized plastic bottles, which were sent to the Milk Quality Laboratory (MQL) situated at the University of Sao Paulo, Luiz de Queiroz campus. The sampling and subsequent analyses of the material were collected once a month, every month, during the years 
of 2011, 2012, 2013, and 2014, totalizing 240 samples. Each month, five farms were randomly sampled out of the total of twelve farms.

Fat content (\%), protein (\%), lactose (\%), dry extract (\%), and total solids (\%) analyses were performed by infrared absorption equipment Bentley 2000 ${ }^{\circledR}$ (Bentley Instruments, Chaska, MN, EUA). Residues for antimicrobial analyses were performed by Delvo Test Kit, as described by Salman et al. ${ }^{(15)}$.

Somatic Cell Count (SCC) and Standard Plate Count (SPC) analyses were performed by Flow Cytometry equipment Somacount $300^{\circledR}$ (Bentley Instruments, Chaska, MN, EUA) and Bactocount IBC ${ }^{\circledR}$ (Bentley Instruments, Chaska, MN, EUA), respectively.

The milk quality parameters were tabulated according to year, month, and source (farm) and represented by median, minimum, and maximum values. The existence of differences in milk quality parameters in relation to year, month, and source factors were analyzed using the nonparametric Kruskal-Wallis Test, since the data was not normally distributed. Statistical analysis was performed using the SPSS 16.0 (SPSS Inc., Chicago, IL, USA) software and the level of significance was set at $\mathrm{p}<0.002$ after accounting for Bonferroni correction (familywise correction: 0.05/21). To verify the correlation between SCC and lactose, Pearson Correlation Analysis was also carried out.

\section{Results}

The median for fat during the period of four years was 5.97\%, and the fat content ranged from $3.5 \%$ to $13.2 \%$. A significant difference $(\mathrm{p}=0.8)$ between the annual medians was not found. When comparing the monthly medians, a significant difference was identified $(\mathrm{p}<0.01)$ during the months that presented the lowest median fat rate $(5.2 \%)$, usually in March (summer), and the month that had the highest rate $(6.5 \%)$, usually October (spring), as showed in Table 1. Regarding the variation amongst the farms, a significant variation for the median $(\mathrm{p}<0.01)$ was found between the lowest count $(5.1 \%)$ and the highest count $(6.9 \%)$, as demonstrated in Table 2.

In the four years, the overall median for protein was calculated at being $4.12 \%$ with the values ranging from $3.06 \%$ to $5.00 \%$. There was no significant difference $(\mathrm{p}=0.881)$ between the annual medians during the analyzed period. As for comparing the likely difference between the months, significant difference was found $(\mathrm{p}<0.00)$. Whilst the months of May and June (autumn) were representative of the lowest median (3.9\%), December (spring) was the month with the highest median $(4.4 \%)$, as showed in Table 1 . As for the dairy farms, there was significant variation of median ( $\mathrm{p}<0.01$ ), being $3.7 \%$ for the lowest count and $4.4 \%$ for the highest score (Table 2).

The median for lactose in the four years was $4.87 \%$ and the lactose content ranged from $3.6 \%$ to $5.3 \%$. However, no significant difference $(\mathrm{p}=0.093)$ was identified between the annual medians. In spite of that, there was a significant difference $(\mathrm{p}<0.00)$ amongst the months, with December and January (summer) showing the lowest median (4.7\%) and April, May, June, and July (autumn/winter) having the highest median $(5.0 \%)$, as showed in Table 1. As for the dairy farm 
units, there was a significant median variation $(\mathrm{p}<0.01)$, being $4.7 \%$ at the lowest count and $5.0 \%$ at the highest count (Table 2). Interestingly, in the present study there was a significant inverse correlation between the SCC and the lactose values.

For dry extract, no significant difference $(\mathrm{p}=0.606)$ was found between the annual medians as well as the months, which showed no significant difference $(\mathrm{p}=0.087)$ (Table 1$)$. The median in the four years was $9.94 \%$ with the values ranging from $7.9 \%$ to $10.5 \%$. Regarding the dairy farms, there was a significant median variation $(\mathrm{p}<0.01$ ), being $9.6 \%$ at the lowest count and $10.3 \%$ at the highest count, as showed in Table 2.

The annual medians for total solids for the period showed no significant difference $(\mathrm{p}=0.091)$. The overall median in the four years was $15.89 \%$ and the total solids value ranged from $11.4 \%$ to $23.4 \%$. When comparing the months, a significant difference $(\mathrm{p}<0.00)$ was found, with March (summer) showing the lowest median (15.2\%) and November (spring) the highest median (16.6\%), as demonstrated in Table 1. As for the studied farms, there was significant variation of medians $(\mathrm{p}<0.01)$, being $15.1 \%$ at the lowest count and $17.0 \%$ at the highest count (Table 2).

In the present study, no antibiotic residues were found in any of the samples analyzed during the period of the study.

The overall median of SCC in the period was $114.78 \times 10^{3}$ cells $/ \mathrm{mL}$ and the values ranged from $35 \mathrm{x}$ $10^{3}$ to $607 \times 10^{3}$ cells $/ \mathrm{mL}$. No significant variation $(\mathrm{p}=0.680)$ was found between annual medians from 2011 to 2014. Regarding the months, no significant difference was found either ( $\mathrm{p}=0.54)$. There was a significant variation $(\mathrm{p}<0.01)$ between the medians of the dairy farms analyzed, being of $47 \times 10^{3}$ cells $/ \mathrm{mL}$ in the lowest count and $168 \times 10^{3}$ cells $/ \mathrm{mL}$ in the highest one.

The median for SPC in the four years was $426.63 \times 10^{3} \mathrm{CFU} / \mathrm{mL}$ with the values ranging from $6 \times 10^{3}$ to $9999 \times 10^{3} \mathrm{CFU} / \mathrm{mL}$. A significant variation $(\mathrm{p}<0.00)$ was found between annual medians from 2011 to 2014, with the highest rate observed in $2013\left(859 \times 10^{3} \mathrm{CFU} / \mathrm{mL}\right)$ and the lowest in 2012 $\left(123 \times 10^{3} \mathrm{CFU} / \mathrm{mL}\right)$. In relation to the dairy calendar year, a significant difference $(\mathrm{p}=0.034)$ was found, and August (winter) was the month with the lowest median $\left(184 \times 10^{3} \mathrm{CFU} / \mathrm{mL}\right)$ and January (summer) was the month that showed the highest median $\left(1687 \times 10^{3} \mathrm{CFU} / \mathrm{mL}\right)$. Regarding the dairy farms, there was a significant median variation $(\mathrm{p}=0.006)$, being $125 \times 10^{3} \mathrm{CFU} / \mathrm{mL}$ in the lowest count and $9999 \times 10^{3} \mathrm{CFU} / \mathrm{mL}$ in the highest one.

\section{Discussion}

The analysis of the samples collected in this study revealed a fat median value of $5.97 \%$. Variation also occurred between the wet and dry seasons, thus agreeing with Hashmi and Saleem ${ }^{(8)}$, who showed that fat and protein values decreased during the hot summer months, whilst lactose content increased in the same period. In the case of the present study, the fat content ranged from $3.5 \%$ to 
Table 1. Milk quality parameters in relation to month of sampling

\begin{tabular}{|c|c|c|c|c|c|c|c|c|}
\hline \multirow[t]{2}{*}{ Month } & & \multirow{2}{*}{$\begin{array}{c}\mathrm{SPC} \\
\left(\mathrm{x} 10^{3} \mathrm{CFU} / \mathrm{mI}\right)\end{array}$} & \multirow{2}{*}{$\begin{array}{c}\mathrm{SCC} \\
\left(\mathrm{x} 10^{3} \text { cells } / \mathrm{ml}\right)\end{array}$} & \multirow{2}{*}{$\begin{array}{l}\text { Fat } \\
(\%)\end{array}$} & \multirow{2}{*}{$\begin{array}{l}\text { Protein } \\
(\%)\end{array}$} & \multirow{2}{*}{$\begin{array}{c}\text { Lactose } \\
(\%)\end{array}$} & \multirow{2}{*}{\multicolumn{2}{|c|}{$\begin{array}{l}\text { Total Solids Dry Extract } \\
\begin{array}{ll}(96) & (96)\end{array}\end{array}$}} \\
\hline & & & & & & & & \\
\hline Jan & Median & 514 & 112 & 6.2 & 4.3 & 4.7 & 16,1 & 9,9 \\
\hline \multirow[t]{2}{*}{ (summer) } & Min & 18 & 35 & 3.5 & 3.3 & 3.6 & 11.4 & 7.9 \\
\hline & Max & 9999 & 303 & 7.7 & 4.6 & 5.2 & 17.6 & 102 \\
\hline Fev & Median & 208 & 139 & 5,9 & 4.3 & 4.8 & 16 & 10,1 \\
\hline \multirow[t]{2}{*}{ (summer) } & Min & 75 & 36 & 5 & 3.7 & 4.4 & 14,3 & 9.3 \\
\hline & Max & 9999 & 196 & 6.7 & 4.6 & 5.1 & 16.7 & 103 \\
\hline Mar & Median & 537 & 114 & 5.2 & 4.2 & 4.9 & $15: 2$ & 10.1 \\
\hline \multirow[t]{2}{*}{ (summer) } & Min & 10 & 39 & 4.6 & 3.6 & 4.7 & 14.5 & 9.6 \\
\hline & Max & 7949 & 25 & 6.6 & 4.5 & 5 & 16.6 & 10.4 \\
\hline Apr & Median & 256 & 101 & 5,3 & 4,1 & 5 & 15.3 & 10 \\
\hline \multirow[t]{2}{*}{ (Autumn) } & Min & 27 & 35 & 4.7 & 3.4 & 4.8 & 14,6 & 9.4 \\
\hline & Max & 9999 & 485 & 6.3 & 4.6 & 5.1 & 16,3 & 10,5 \\
\hline Mai & Median & 267 & 78 & 5.7 & 3.9 & 5 & 15,6 & 9,8 \\
\hline \multirow[t]{2}{*}{ (Autumn) } & Min & 6 & 52 & 4 & 3 & 5 & 14 & 9 \\
\hline & Max & $59 \$ 2$ & 210 & 8.3 & 4.2 & 5.3 & 17.5 & 102 \\
\hline Jun & Madian & 200 & 95 & 6 & 3.9 & 5 & 15.8 & 9.8 \\
\hline \multirow[t]{2}{*}{ (Autumn) } & Min & 19 & 53 & 5 & 3 & 5 & 14 & 9 \\
\hline & Max & 2468 & $36 !$ & 6.9 & 4.3 & 5.1 & 17 & 102 \\
\hline Jul & Median & 306 & 107 & 6.1 & 4 & 5 & 16 & 9.9 \\
\hline \multirow[t]{2}{*}{ (winter) } & Min & 6 & 41 & 5 & 3 & 4 & 15 & 9 \\
\hline & Max & 4623 & 607 & 7 & 4.3 & 5.1 & 17.1 & 10.4 \\
\hline Aug & Median & 184 & 145 & 6,2 & 4.1 & 4.9 & 16 & 9.9 \\
\hline \multirow[t]{2}{*}{ (winter) } & Min & 15 & 96 & 4.7 & 3.5 & 4.6 & 14.5 & 9.4 \\
\hline & Max & 7370 & 245 & 7.1 & 4.6 & 5.1 & 17,3 & 10.4 \\
\hline Sep & Median & 242 & 116 & 6.3 & 4.1 & 4.8 & 16.2 & 9.9 \\
\hline \multirow[t]{2}{*}{ (winter) } & Min & 11 & 47 & 4.4 & 3.4 & 4.4 & 14.3 & 9.3 \\
\hline & Max & 1325 & 285 & 7 & 5 & 5 & 18 & 10 \\
\hline Out & Madian & 218 & 144 & 6.5 & 4.2 & 4.8 & 16.5 & 10 \\
\hline \multirow[t]{2}{*}{ (spring) } & Min & 17 & 42 & 4.1 & 3.7 & 4.2 & 13.2 & 9.1 \\
\hline & Max & 9999 & 450 & 13.2 & 5 & 5 & 23.4 & 10.4 \\
\hline Nov & Median & 1687 & 129 & 6.4 & 4.3 & 4.8 & 16,6 & 10 \\
\hline \multirow[t]{2}{*}{ (spring) } & Min & 45 & 86 & 4.5 & 3.9 & 3.9 & 13.6 & 9.1 \\
\hline & Max & 9999 & 551 & 7.8 & 5 & 5 & 17.5 & 103 \\
\hline Dez & Median & 495 & 96 & 6.4 & 4.4 & 4.7 & 16.3 & 10 \\
\hline \multirow[t]{2}{*}{ (spring) } & Min & 74 & 48 & 4.2 & 3.8 & 4,1 & 13 & $\$ .8$ \\
\hline & Max & 9999 & 284 & 7.6 & 4.6 & 5 & 17.6 & 103 \\
\hline
\end{tabular}


Table 2. Milk quality parameters in relation to the farms

\begin{tabular}{|c|c|c|c|c|c|c|c|c|}
\hline Farm & & $\begin{array}{c}\mathrm{SPC} \\
\left(\times 10^{3} \mathrm{CFU} / \mathrm{ml}\right)\end{array}$ & $\begin{array}{c}\text { SCC } \\
\left(x 10^{3} \text { cells } / \mathrm{ml}\right)\end{array}$ & $\begin{array}{l}\text { Fat } \\
(\%)\end{array}$ & $\begin{array}{c}\text { Protein } \\
(\%)\end{array}$ & $\begin{array}{c}\text { Lactose } \\
(\%)\end{array}$ & $\begin{array}{c}\text { Total Solids } \\
(\%)\end{array}$ & $\begin{array}{c}\text { Dry Extract } \\
(\%)\end{array}$ \\
\hline \multirow{3}{*}{1} & Median & 191 & 143 & 5.1 & 4.2 & 4.7 & 15.1 & 10 \\
\hline & Min & 6 & 56 & 35 & 3.3 & 3.6 & 11.4 & 79 \\
\hline & $\operatorname{Max}$ & 6181 & 450 & 13.2 & 4.5 & 5 & 23.4 & 10.2 \\
\hline \multirow{3}{*}{2} & Median & 330 & 120 & 6 & 4.1 & 4.9 & 15.9 & 10 \\
\hline & Min & 6 & 65 & 49 & 3.7 & 4.1 & 14.7 & 9.2 \\
\hline & Max & 9999 & 607 & 72 & 4.6 & 5.3 & 17.5 & 10.4 \\
\hline \multirow{3}{*}{3} & Median & 1343 & 127 & 63 & 4.2 & 4.9 & 16.1 & 9.9 \\
\hline & Min & 18 & 68 & 5 & 3.6 & 4.4 & 14.9 & 9.5 \\
\hline & Max & 9999 & 303 & 7.4 & 4.5 & 5.1 & 17.6 & 10.3 \\
\hline \multirow{3}{*}{$4^{*}$} & Median & 216 & & & & & & \\
\hline & Min & 216 & & & & & & \\
\hline & Max & 216 & & & & & & \\
\hline \multirow{3}{*}{5} & Median & 125 & 87 & 6.1 & 4.4 & 4.9 & 16.2 & 10.3 \\
\hline & Min & 46 & s8 & 5.6 & 3.7 & 4.7 & 15.9 & 9.2 \\
\hline & Max & 6687 & 167 & 83 & 4.6 & 5.1 & 17.5 & 10.5 \\
\hline \multirow{3}{*}{6} & Median & 202 & 99 & 6,3 & 4 & 5 & 16.1 & 9.8 \\
\hline & Min & 15 & 52 & 5.1 & 3.5 & 4.1 & 15 & 9.4 \\
\hline & Max & 9999 & 551 & 7.8 & 4.6 & 5.1 & 17.6 & 10.2 \\
\hline \multirow{3}{*}{7} & Median & 882 & 77 & 62 & 3.8 & 5 & 15.8 & 9.7 \\
\hline & Min & 62 & 35 & 49 & 3.4 & 4.6 & 14.5 & 9.3 \\
\hline & Max & 9999 & 241 & 69 & 4.6 & 5.2 & 17.2 & 10.3 \\
\hline \multirow{3}{*}{8} & Median & 972 & 101 & 6.7 & 4,3 & 4.9 & 16,9 & 10.1 \\
\hline & Min & 62 & 62 & 4.7 & 3.9 & 3.9 & 14,9 & 9.9 \\
\hline & Max & 9999 & 358 & 7.6 & 5 & 5.1 & 17.8 & 10.4 \\
\hline \multirow{3}{*}{9} & Median & 9999 & 47 & 69 & 4.1 & 4.9 & 17 & 10.1 \\
\hline & Min & 512 & 42 & 6.8 & 3,9 & 4,6 & 16,2 & 9.5 \\
\hline & Max & 9999 & 87 & 7 & 4.3 & 5 & 17.2 & 10.2 \\
\hline & Median & 417 & 168 & 63 & 4.1 & 5 & 16.1 & 9.8 \\
\hline \multirow[t]{3}{*}{10} & Min & 28 & 94 & 5.8 & 3.6 & 4.6 & 15.7 & 9.5 \\
\hline & Max & 9999 & 485 & 7 & 4.4 & 5.1 & 17.1 & 10.4 \\
\hline & Median & 229 & 55 & 5.4 & 3.7 & 4.9 & 15.2 & 9.6 \\
\hline \multirow[t]{3}{*}{11} & Min & 21 & 35 & 52 & 3.1 & 4.8 & 14.5 & 9.2 \\
\hline & Max & 1955 & 209 & 69 & 4.1 & 5,1 & 16.5 & 9.9 \\
\hline & Median & 1410 & 56 & 65 & 4.3 & 4.8 & 16.6 & 10 \\
\hline \multirow[t]{2}{*}{12} & Min & 178 & 36 & 6 & 4 & 4.8 & 15,9 & 9.8 \\
\hline & Max & 1878 & 158 & 6.6 & 4.3 & 4.8 & 16.6 & 10.1 \\
\hline
\end{tabular}

- Problem with sampling in Farm 4, only SPC analysis available. 
$13.2 \%$, which contrasted to those results found by Yasmim et al. ${ }^{(16)}$. They observed a smaller fat content ranging from $4.3 \%$ to $5.4 \%$. Yet, the present study found a significant difference $(\mathrm{p}<0.01)$ among the medians of the months, where March (summer) showed a lower fat rate $(5.2 \%)$ and October (spring) being the month with the highest fat rate $(6.5 \%)$, as showed in Table 1. Coelho et al. ${ }^{(17)}$ found average values of $6.81 \%$ for fat, yet, similarly to the findings of this present study, their results showed that fat content decreased during the hot summer months. It could therefore be inferred that it is likely that the drop in fat content effect was caused by thermal stress of the animals; however, further investigation would be needed to better understand this correlation.

Regarding the protein content, buffalo milk has higher protein content than that of the cow (Bos taurus $)^{(3)}$. Tonhati et al. ${ }^{(2)}$ and Jorge et al. ${ }^{(6)}$ found overall means for protein of $3.9 \%$ and $3.92 \%$, respectively, and these values were very close to those found in the present study. The results from many examples in Brazil agree to those of Pakistan, which showed similar higher protein values as proposed by Yasmin et al. ${ }^{(16)}$. In the Pakistani case, the mean protein ranged from $2.3 \%$ to $3.22 \%$ throughout the year with lower values being observed during the summer months. However, in Brazil, Macedo et al. ${ }^{(5)}$ found higher average levels of total protein content for Murrah animals to be 4.13\%. Conversely, the lowest value obtained, 3.68\%, occurred in August (winter) and the highest, $4.79 \%$, in February (summer). Yet, the present study has indicated that significant differences occurred during the calendar year with May and June (autumn) representing the lowest median (3.9\%), and December (spring) the highest median (4.4\%), as showed in Table 1.

Buffalo milk is also a richer source of lactose than that of the European cow, camel, goat, or sheep's milk. It is a good source of energy for body activities particularly for the brain function and hormonal regulation ${ }^{(3)}$. As for the seasonal monthly variation, the values found for lactose agreed with those found by Yasmin et al. ${ }^{(16)}$, who observed the highest lactose content $(6.26 \%)$ happened during a cold month and the lowest one $(4.93 \%)$ in a warm month. However, Coelho et al. ${ }^{(17)}$ found average values of $5.02 \%$ for lactose, which was reported to increase during the hot summer months. Interestingly, in the present study, there was a significant inverse correlation between the SCC and lactose values. In Pakistan, Sharif et al. ${ }^{(18)}$ observed an increase in SCC due to udder infection, which resulted in lower lactose content and higher proteolysis values; therefore, affecting milk total solids, and consequently, its value.

Regarding dry extract, Macedo et al. ${ }^{(5)}$ and Hashmi and Saleem (8) found an overall mean of dry extract of $10.47 \%$ and $8.56 \%$, respectively, which is close to the median of $9.94 \%$ of dry extract found in this study. Differences in breeds, management, feeding, and environmental conditions under which the herd was kept must be considered to better understand their interaction with the composition of buffalo milk. Although Coelho et al. ${ }^{(17)}$ found an overall average of significantly higher values for dry extract to occur more during the winter months than in the summer, the present study did not present any significant difference among the months $(\mathrm{p}=0.087)$.

For total solids, Macedo et al. ${ }^{(5)}$ and Jorge et al. ${ }^{(6)}$ found an average level of $17.01 \%$ and $13.88 \%$, respectively. The present study found a median of $15.89 \%$, which is also close to the result obtained by Hashmi and Saleem ${ }^{(8)}$, who found a mean value of $16.38 \%$. In relation to the period studied, there was a significant difference of total solids amongst the medians, where March (summer) presented the lowest median (15.2\%) and November (spring) the highest one (16.6\%). Coelho et al. ${ }^{(17)}$ found an average value of $17.23 \%$ for total solids, which tended to decrease during the hot summer months, similarly to the results found in the present study.

All of the samples analyzed from the twelve farms between January 2011 and December 2014 
showed a negative result for antimicrobial drug traces. This indicates that for the sample studied the dairy farmers have been following the Brazilian legislation to the letter. However, experience from other countries, as showed by Movassagh ${ }^{(19)}$, indicated that when the detection of antibiotic in buffalo milk was investigated, antibiotic residues were found to be present in $6 \%$ of the buffalo milk samples in the region of Meshkinshahr in Iran. Other positive cases were also found in cow milk (Bos taurus) in Trinidad, as mentioned by Adesiyun and $\mathrm{Webb}^{(20)}$, who found that $10.8 \%$ of samples were positive for antimicrobial residues. Moreover, Shitandi ${ }^{(21)}$ reported that $21 \%$ of milk samples were also positive for antibiotic residues in Kenya, and according to Alomirah et al. ${ }^{(22)}$, $5.4 \%$ of imported pasteurized milk samples and 3.4\% of local pasteurized samples were positive for antibiotic residues in Kuwait. Another example is the one by Khaskheli et al. ${ }^{(23)}$, who found that $37 \%$ of the samples were positive for Beta Lactam antibiotic residues in raw cow milk (Bos taurus) also in Pakistan.

Table 3: Analysis of Milk Quality Parameters

\begin{tabular}{lccc}
\hline & YEAR & MONTH & FARM \\
\hline SPC $\left(1 \times 10^{3}\right.$ CFU $/ m$ l) & $\mathrm{p}<0.00^{*}$ & $\mathrm{p}=0.034$ & $\mathrm{p}=0.006$ \\
$\operatorname{SCC}\left(1 \times 10^{3}\right.$ cells/ml) & $\mathrm{p}=0.680$ & $\mathrm{p}=0.54$ & $\mathrm{p}<0.01^{*}$ \\
Fat $\%(\mathrm{~m} / \mathrm{m})$ & $\mathrm{p}=0.80$ & $\mathrm{p}<0.01^{*}$ & $\mathrm{p}<0.01^{*}$ \\
Protein $\%(\mathrm{~m} / \mathrm{m})$ & $\mathrm{p}=0.881$ & $\mathrm{p}<0.00^{* *}$ & $\mathrm{p}<0.01^{*}$ \\
Lactose $\%(\mathrm{~m} / \mathrm{m})$ & $\mathrm{p}=0.093$ & $\mathrm{p}<0.00^{*}$ & $\mathrm{p}<0.01^{*}$ \\
Total Solids \%(m/m) & $\mathrm{p}=0.091$ & $\mathrm{p}<0.00^{*}$ & $\mathrm{p}<0.01^{*}$ \\
Dry Extract $\%(\mathrm{~m} / \mathrm{m})$ & $\mathrm{p}=0.606$ & $\mathrm{p}=0.087$ & $\mathrm{p}<0.01^{*}$ \\
\hline
\end{tabular}

SCC - somatic cell counting;

SPC. standard plate count;

(*) Statistically significant at p<0.002 (Bonferroni correction) analyzed by Kruskal Wallis Test.

It is important to point out that specific legislation is lacking to determine the identity and quality pattern of buffalo milk. According to the Brazilian legislation for cow milk ${ }^{(24)}$, which serves as reference, the SCC should correspond to a maximum $400 \times 10^{3}$ cells $/ \mathrm{mL}$ (this value is expected to go down to $360 \times 10^{3}$ by July 1,2016 ). The presence of SCC above $200 \times 10^{3}$ cells $/ \mathrm{mL}$ is usually associated with infection, mainly mastitis ${ }^{(25)}$. Since the samples analyzed in the present study found a median value of $114.78 \times 10^{3}$ cells $/ \mathrm{mL}$, Brazilian buffalo dairy producers are adhering to the present legislation, although values outside the reference range have been found (Table 2). Pizauro et al. (26) studied the prevalence and etiology of buffalo mastitis and milk somatic cell count during the dry and rainy seasons in a buffalo herd in the state of São Paulo, Brazil. They observed that, regarding the SCC count, milk samples with acceptable results in microbiological tests showed average values of $99.51 \times 10^{3}$ cells $/ \mathrm{mL}$ and $125.6 \times 10^{3} \mathrm{cells} / \mathrm{mL}$ during cold and warm periods, respectively. On the other hand, milk samples with unacceptable results presented average values of $137.72 \times 10^{3} \mathrm{cells} / \mathrm{mL}$ and $190.3 \times 10^{3} \mathrm{cells} / \mathrm{mL}$ in cold and warm seasons, respectively, indicating the 
presence of infection in the high levels. In relation to the present study, May (autumn) was found to be the month with the lowest SCC median and July (winter) the month with the highest SCC median, indicating that in the cold weather, the animals are less susceptible to mammary infections.

Regarding the SPC, the Brazilian legislation ${ }^{(24)}$ establishes that the SPC should be the maximum $1 \times 10^{5} \mathrm{CFU} / \mathrm{mL}$. The present study showed high values of SPC, showing the Brazilian dairy farmers falling far from adhering to the accepted CFU limits as established by the current legislation. This is probably due to poor milking hygiene and deficient transport (time of milk collection, delay in transport, exposure to sunshine, and high room temperature). Similarly to milk components, the microbiological quality of milk changes according to the temperature of the surrounding environment. Hashmi and Saleem ${ }^{(8)}$ found the mean SPC tended to increase during the warm months. Similar results were found in the present study, where significant difference between the months: August (winter) was the month with the lowest average and November (spring) was the month with the highest average. The main reason for these relatively higher counts of SPC could also be ascribed to poor hygiene conditions during milking, collection and transport (that in days with high temperature can promote the proliferation of mesophilic bacteria in milk).

\section{Conclusions}

The median of SCC was in line with the Brazilian legislation; however, higher values were found for the SPC values, which indicate poor hygiene during milking, transportation, and storage. As for the present study, there was significant average variation amongst all dairy farms studied regarding all chemical and microbiological parameters analyzed, proving that there is such a difference in quality between suppliers that will rebound on the profitability of by-products. We suggest that price incentives paid for the quality of raw milk could be a strategy to dairy processing companies, favoring yield and quality of the final product.

For analyses of antibiotic residues all samples showed to be negative, revealing that Brazilian producers are respecting the legislation. The present study showed that there were variations of fat, protein, lactose, total solids, and SPC among the seasons, serving as a good basis for further future investigations to better understand the dairy farmers' management practices and how they affect milk quality, suggesting further studies to relate the main causes. It is worth emphasizing the importance of elaborating specific legislation for buffalo milk and derivatives so as to officially characterize the parameters of product quality

\section{References}

1.Araújo TPM, Rangel AHDN, Soares AD, Lima TCCD, Lima Júnior DMD, Novaes LP. [Influence of seasons on buffalo milk composition held in the cooling tank] Agropecuária Científica no Semiárido. 2011; 7(1):01-05.

2. Tonhati H, Múñoz MC, de Oliveira JÁ, Duarte JC, Furtado TP, Tseimazides SP. Genetic parameters for the production of milk, fat and protein in buffalo. Revista Brasileira de Zootecnia. 2000; 29(6):2051-2056. 
3. Ahmad S, Anjum FM, Huma N, Sameen A, Zahoor T. Composition and physico-chemical characteristics of buffalo milk with particular emphasis on lipids, proteins, minerals, enzymes and vitamins. The Journal of Animal and Plant Sciences. 2013; 23:62-74.

4. Varrichio ML, Di Francia A, Masucci F, Romano R, Proto V. Fatty acid composition of Mediterranean buffalo milk fat. Italian Journal of Animal Science. 2007; 6:509-511.

5. Macedo MP, Wechsler FS, Ramos AA, Amaral JB, Souza JC, Resende FD, Oliveira JV. Chemical composition and production of milk from Mediterranean buffalo cows raised in western of São Paulo State, Brazil. Revista Brasileira de Zootecnia. 2001; 30:1084-1088.

6. Jorge AM, Andrighetto C, Stazza MRB, Correa RC, Kasburgo DG, Piccinin A, Victória C, Domingues PF. Correlation between the California Mastitis Test (CMT) and somatic cells count in milk from Murrah buffalo cows. Revista Brasileira de Zootecnia. 2005; 34:2039-2045.

7. Cicconi-Hogan KM, Gamroth M, Richert R, Ruegg PL, Stiglbauer KE, Schukken YH. Associations of risk factors with somatic cell count in bulk tank milk on organic and conventional dairy farms in the United States. Journal of Dairy Science. 2013; 96:3689-3702.

8. Hashmi S, Saleem Q. Microbiological and chemical analysis of buffalo milk supplies of beed district. Journal of Advances in Applied Sciences and Technology. 2014; 1:20-24.

9. Gunasekera TS, Veal DA, Attfield PV. Potential for broad applications of flow cytometry and fluorescence techniques in microbiological and somatic cell analyses of milk. International Journal of Food Microbiology. 2003; 85:269-279.

10. Gargouri A, Hamed H, Elfeki A. Analysis of Raw Milk Quality at Reception and During Cold Storage: Combined Effects of Somatic Cell Counts and Psychrotrophic Bacteria on Lipolysis. Journal of Food Science. 2013; 78:1405-1411.

11. WHO (World Health Organization). 2008. Chapter 8: maximum residue limits for pesticides and veterinary drugs. Principles and methods for the risk assessment of chemicals in food. http://www.who.int/foodsafety/chem/residue_limits.pdf

12. FAO (Food and Agriculture Organization). 2012. Maximum Residue Limits for Veterinary Drugs in Foods. Codex Alimentarius Commission.1:40 ftp://ftp.fao.org/codex/weblinks/MRL2_e_2012.pdf

13. Khaniki GR. Chemical contaminants in milk and public health concerns: a review. International Journal of Dairy Science. 2007; 2(2):104-15.

14. Sharif A, Muhammad G. Somatic cell count as an indicator of udder health status under modern dairy production: a review. Pakistan Veterinary Journal. 2008; 28:194-200.

15. Salman AM, ElNasri HA, Osman IAM. Detection of antibiotic residues in milk using delvotest kit and the disc assay methods in Khartoum state, Sudan. Journal of Veterinary Medicine and Animal Production. 2012; 3(2): 3-15.

16. Yasmin A, Huma N, Butt MS, Zahoor T, Yasin M. Seasonal variation in milk vitamin contents available for processing in Punjab, Pakistan. Journal of the Saudi Society of Agriculture Sciences. 2012; 11:99-105.

17. Coelho KO, Machado PF, Coldebella A, Cassoli LD, Corassin CH. [Determination of physical-chemical pattern of buffalo milk samples using automatic analyzers] Ciência Animal Brasileira. 2004; 5:167-170.

18. Sharif A, Ahmad T, Bilal MQ, Yousaf A., Muhammad G. Estimation of milk lactose and somatic cells for the diagnosis of sub-clinical mastitis in dairy buffaloes. International Journal of Agriculture and Biology. 2007; 9:267-270.

19. Movassagh MH. Detection of Antibiotic Residues in the Water Buffalo Milk in Meshkinshahr, Ardabil Province, Iran. Global Veterinaria. 2011; 7(2): 199-200. 
20. Adesiyun AA, Webb LA. Prevalence of antimicrobial residues in preprocessed and processed cow's milk in Trinidad. Journal of Food Safety. 1997; 16:301-310.

21. Shitandi, A. Detection of antimicrobial drug residues in Kenyan milk. Journal of Food Safety. 2001; 21:205-214.

22. Alomirah H, Almazeedi H, Alzenkee S, Alaati T, Alotaibi J, Albatel M, Sidhu, J. Prevalence of antimicrobial residues in milk and dairy products in the state of Kuwait. Journal of Food Quality. 2007; 30:745-763.

23. Khaskheli MRS, Malik RS, Arain MA, Soomro A.H., Arain HH. Detection of beta-lactam antibiotic residues in market milk. Pakistan Journal of Nutrition. 2008; 7(5):682-685.

24. Brasil. 2011. [Ministry of Agriculture, Livestock and Supply]. Instruction $n^{\circ} 62$ of December $29^{\text {th }} 2011$. Regulation Production Technician, identity, quality, collection and milk transport. Official Gazette, Executive Power. Brasília, DF, Brazil, Section 1.]

25. Pinzón-Sánchez C, Ruegg PL. Risk factors associated with short-term post-treatment outcomes of clinical mastitis. Journal of dairy science. 2011; 94(7): 3397-3410.

26. Pizauro LJL, Silva DG, Santana AM, Clemente V, Lara G.H.B., Listoni F.J.P., Vaz A.C.N., VidalMartins AMC, Ribeiro MG, Fagliari JJ. Prevalence and etiology of buffalo mastitis and milk somatic cell count in dry and rainy seasons in a buffalo herd from Analândia, São Paulo State, Brazil. Arquivo Brasileiro de Medicina Veterinária e Zootecnia. 2014; 66:1703-1710. 